\title{
Epidemiologic and clinical study of skin cancer in the insular regions of Italy
}

\author{
F Stagno d'Alcontres ${ }^{*}$, M C Scarcella, B Manasseri, F Lupo \\ From de Senectute: Age and Health Forum \\ Catanzaro, Italy. 5-7 December 2009
}

\section{Background}

Skin tumors, including Epithelial tumors, Adnexal tumors, Merkel carcinoma and Melanoma, are a prominent disease of advanced age, with a frequency of 40 cases /year for 100,000 people and a mortality of $1 \%$ [1].

Ethiopatogenesis is correlated with external factors, above all UV exposition, and skin and adnexal phenotypes; for this reason people from the regions of insular Italy are more at risk from this pathological state.

\section{Materials and methods}

This study is an analysis of skin tumors that have been treated in the last 10 years in our Department of Plastic Surgery. We have considered the age incidence, sex incidence, localization and histotype.

\section{Results}

From the elaboration of data it emerged that male patients, within an age range of 60 to 80 years old, are the most affected by this disease.

The most frequent locations that present these conditions are the cervical-facial region, followed by the trunk/thorax, upper limbs and lower limbs.

Epithelial tumors, basal cell Carcinoma and squamous cell Carcinoma, have a much higher incidence than adnexal Carcinoma and Merkel carcinoma: particularly the basal cell $\mathrm{Ca}$ which has an incidence of $72 \%$, Squamous cell $\mathrm{Ca}$ represents $18 \%$ of epithelial tumors, adnexal $\mathrm{Ca}$ are about $1.5 \%$ and Merkel $\mathrm{Ca}$ has an even lower incidence.

Finally, we cannot neglect melanomas, sarcomas and cutaneous linfomas which have an incidence of $6 \%$.

\section{Conclusions}

The analysis of these data has emphasized the high morbidity of this disease which more often than not reaches the specialist at a very advanced stage.

The objective of this study is to highlight the high incidence of this disease in the regions of insular Italy and the clinical and social implications, in order to bring about an effective plan of prevention, [2-4].

Published: 19 May 2010

\section{References}

1. Stagno d'Alcontres $F$, et al: Indagine clinico statistica su 3495 tumori della cute. Derm Clin n. 1996, 2:99-105.

2. Micali G: Considerazioni clinico-statistiche sull'epitelioma basocellulare. Atti 67 Congr. Naz. S.I.C.O. La Garangola Ed. 1983, 181.

3. Soma PF, Micali G, Moschella F: Note sulla epidemiologia e clinica dell'epitelioma basocellulare. Folia Oncol 1984, 68(SupplB).

4. Khaled $A$, Ben MbareK $L$, et al: Epidemiologic study of cutaneous cancers in aged persons.

\section{doi:10.1186/1471-2318-10-S1-A80}

Cite this article as: d'Alcontres et al.: Epidemiologic and clinical study of skin cancer in the insular regions of Italy. BMC Geriatrics 2010 10(Suppl 1):A80.

Department of Plastic Surgery, University of Messina, Italy

Submit your next manuscript to BioMed Central and take full advantage of:

- Convenient online submission

- Thorough peer review

- No space constraints or color figure charges

- Immediate publication on acceptance

- Inclusion in PubMed, CAS, Scopus and Google Scholar

- Research which is freely available for redistribution
C Biomed Central 